\title{
Removal of harmful cyanobacterial blooms in Taihu Lake using local soils. III. Factors affecting the removal efficiency and an in situ field experiment using chitosan-modified local soils
}

\author{
Gang Pan*, Hua Zou, Hao Chen, Xianzheng Yuan \\ State Key Laboratory of Environmental Aquatic Chemistry, Research Center for Eco-environmental Sciences, \\ Chinese Academy of Sciences, Beijing 100085, China
}

Received 8 March 2005; accepted 8 August 2005

A loading of $0.025 \mathrm{~g} / \mathrm{L}$ chitosan-modified local soils removed $99 \%$ algal cells in $16 \mathrm{~h}$ in a field enclosure of Taihu Lake.

\begin{abstract}
Effects of ionic strength, $\mathrm{pH}$, organic content, cell concentration, and growth phase on the removal of MA cells using chitosan-modified sepiolite were studied in the laboratory. The MA removal efficiency increased with the increase of salinity for normal clay flocculation. In contrast, for chitosan-modified clays/soils, MA removal efficiency increased with the decrease of salinity. The removal efficiency of chitosan-modified sepiolite was not significantly affected by $\mathrm{pH}$ (6-9), but dropped dramatically beyond $\mathrm{pH} 10$. Humic acid had a small negative effect on the removal of MA cells. Cells were removed more effectively by clays around the early senescence growth phase than other growth stages. The removal efficiency increased as the cell concentration increased. In a field enclosure of Taihu Lake, a loading of $0.025 \mathrm{~g} / \mathrm{L}$ chitosan-modified local soils removed $99 \%$ algal cells and no increase of chlorophyll- $a$ was observed during the following one month's monitoring process.
\end{abstract}

(C) 2005 Elsevier Ltd. All rights reserved.

Keywords: Harmful cyanobacterial blooms; Clays; Chitosan-modified clay; Flocculation; Ionic strength; Organic content; pH; Cell concentration; Growth stage

\section{Introduction}

In previous studies we reported that the chitosan modification technique could turn many clays, minerals, and local soils into highly effective flocculants to remove harmful cyanobacterial blooms by increasing their netting and bridging function (Zou et al., 2004, 2006). In order to provide better guidance for practical use in the field around Taihu Lake, it is necessary to study how various factors affect the performance of this technique. It is known that the flocculation efficiency of clays generally decreases as salinity decreases (Han and Kim, 2001) so that the clay technique has been used mainly in salty water

\footnotetext{
* Corresponding author. Tel.: +8610 62849686; fax: +861062923563.

E-mail address: gpan@mail.rcees.ac.cn (G. Pan).
}

systems in the past. Although polyaluminum chloride (PAC) (Sengco et al., 2001; Pierce et al., 2004) and sophorolipid (Baek et al., 2003; Sun et al., 2004) have recently been used to modify clays, no studies were found whether the abovementioned ionic strength effect on clay flocculation could be reversed after the clays, minerals, soils were modified by netting and bridging reagents such as chitosan. In Taihu Lake, harmful cyanobacterial blooms normally occur between June and November, where $\mathrm{pH}$ could change from 6.7 to 9.0 and the average algal concentration from $10^{6}$ to $10^{9}$ cells/L. In many places in surface water, the algal concentration could be much higher. These conditions could also affect the efficiency and clay loadings used to clean the blooms. Also, the viscosity and other surface properties as well as the gravity of the cells vary at different growth stages, which could affect the affinity between the cells and the clay particles used (Chen 
et al., 2004). Here, the effects of ionic strength, $\mathrm{pH}$, organic content of water, cell concentration and growth phase on the removal of MA using chitosan-modified sepiolite were studied in laboratory experiments.

Guided by the laboratory results presented in this series of study, a practical application of chitosan-modified local soils to remove harmful cyanobacterial blooms in field enclosures in Meiliang Bay of Taihu Lake was conducted in SeptemberOctober 2004. The short term effect and the long term monitoring results are reported here.

\section{Materials and methods}

\subsection{Materials and treatments}

The materials used here, such as clays, minerals, Taihu Lake local soils, chitosan and MA strains, were described in previous studies (Pan et al., 2006; Zou et al., 2006). The treatment of the materials, the flocculation experiments, the instrumental settings, and the analytical procedures were the same as those described before (Pan et al., 2006; Zou et al., 2006).

\subsection{Influence of ionic strength on the flocculation of chitosan-modified clays}

The ionic strength effect was tested with $500 \mathrm{~mL}$ jar test experiments in $\mathrm{NaCl}$ solutions of the following concentrations: $0 \%, 0.01$ or $0.05 \%, 0.1 \%$, $0.2 \%, 0.5 \%$ and $1 \%$, equivalent to ionic strengths of $0 \mathrm{~mol} / \mathrm{L}, 0.0017$ or $0.0085 \mathrm{~mol} / \mathrm{L}, \quad 0.017 \mathrm{~mol} / \mathrm{L}, \quad 0.0342 \mathrm{~mol} / \mathrm{L}, \quad 0.085 \mathrm{~mol} / \mathrm{L}$ and $0.17 \mathrm{~mol} / \mathrm{L}$. Chitosan-modified clay loadings used for laboratory experiments were $11 \mathrm{mg} / \mathrm{L}$, which consisted of $1 \mathrm{mg} / \mathrm{L}$ chitosan and $10 \mathrm{mg} / \mathrm{L}$ clays. For unmodified sepiolite and kaolinite, a clay loading of $700 \mathrm{mg} / \mathrm{L}$ was used in the ionic strength experiment (unmodified clays show no removal of MA cells at a clay loading of $11 \mathrm{mg} / \mathrm{L}$ ). Conditions of initial MA concentration and $\mathrm{pH}$ were fixed to $4.86 \times 10^{9}$ cells $/ \mathrm{L}$ and 7.0 , respectively.

\subsection{Influence of $\mathrm{pH}$ on the flocculation of chitosan-modified clays}

Different $\mathrm{pH}(6.0-10.0)$ was controlled by adding either $0.1 \mathrm{M} \mathrm{HCl}$ or $0.1 \mathrm{M} \mathrm{Na}_{2} \mathrm{CO}_{3}$ solutions before and during the flocculation experiment. Conditions of initial MA concentration, chitosan-modified sepiolite loading, and ionic strength were fixed at $4.86 \times 10^{9}$ cells/L, $11 \mathrm{mg} / \mathrm{L}$, and $0.5 \% \mathrm{NaCl}$ $(0.085 \mathrm{~mol} / \mathrm{L})$, respectively.

\subsection{Influence of organic content on the flocculation of chitosan-modified clays}

To simulate the organic matter content, humic acid was added in the flocculation experiments at $0 \mathrm{mg} / \mathrm{L}, 4 \mathrm{mg} / \mathrm{L}, 10 \mathrm{mg} / \mathrm{L}, 20 \mathrm{mg} / \mathrm{L}$ and $40 \mathrm{mg} / \mathrm{L}$ (equivalent to about $0-55 \mathrm{mg} / \mathrm{L}$ COD $(\mathrm{Cr})$ ). The original Taihu Lake water used in the experiment had a COD $(\mathrm{Cr})$ of $40 \mathrm{mg} / \mathrm{L}$. Conditions of initial MA concentration, chitosan-modified sepiolite loading, ionic strength, and $\mathrm{pH}$ were fixed at $4.86 \times 10^{9}$ cells $/ \mathrm{L}, 11 \mathrm{mg} / \mathrm{L}, 0.5 \% \mathrm{NaCl}(0.085 \mathrm{~mol} / \mathrm{L})$, and 7.0 , respectively.

\subsection{Influence of cell concentration on the flocculation of chitosan-modified clays}

Different initial concentrations of MA cells were used for the jar-test flocculation experiment. Conditions of chitosan-modified sepiolite loading, ionic strength, and $\mathrm{pH}$ conditions were fixed to $11 \mathrm{mg} / \mathrm{L}, 0.085 \mathrm{~mol} / \mathrm{L}(0.5 \%$ $\mathrm{NaCl}$ ), and 7.0, respectively.
2.6. Influence of growth stage on the flocculation of unmodified sepiolites

MA cells at different growth stage, i.e., day 9 (late lag phase), day 14 (middle logarithmic phase), day 22 (late logarithmic phase), and day 27 (early senescence phase) were harvested for the flocculation experiment. Conditions of initial cell concentration, unmodified sepiolite loading, ionic strength, and $\mathrm{pH}$ were fixed at $4.86 \times 10^{9} \mathrm{cells} / \mathrm{L}, 200 \mathrm{mg} / \mathrm{L}, 0.5 \% \mathrm{NaCl}(0.085 \mathrm{~mol} / \mathrm{L})$, and 7.2 , respectively.

\subsection{Field enclosure experiment in Taihu Lake}

Field experiments were conducted in two circular enclosures in Meiliang Bay of Taihu Lake. Each enclosure was about $32 \mathrm{~m}^{2}$ in area and about $2 \mathrm{~m}$ deep. The enclosures were made of polyvinyl chloride (PVC) and there was no exchange between the waters inside and outside of the enclosures. Initial chlorophyll- $a$ concentration was about $2 \mathrm{mg} / \mathrm{L}$ (before the field treatment). An average of $1.5 \mathrm{~kg}$ of chitosan-modified local soils were sprayed into the operating enclosure (contained 10\% chitosan). The other enclosure was used as a control. Both chlorophyll and phosphate concentrations in the enclosures were monitored through out the rest of 33 days. The growth of mussels (Cristaria plicata (Leach)) and submerged maerophyte (Myriophyllum spicatum) were also monitored in the operating enclosure and the control enclosure.

\section{Results}

\subsection{Contrast effect of ionic strength on normal clay flocculation and chitosan-modified clay flocculation}

For unmodified sepiolite and kaolinite, the removal efficiencies increased with the increase of ionic strength (Fig. 1a and b). The removal efficiency $\left(Q_{8 \mathrm{~h}}\right)$ by unmodified sepiolite was more than $95 \%$ in $1 \% \mathrm{NaCl}$ solution and reduced to below $70 \%$ in $0 \% \mathrm{NaCl}$ solution. Under the same conditions, $Q_{8 \mathrm{~h}}$ of unmodified kaolinite decreased from $80 \%$ to $50 \%$.

In contrast, for chitosan-modified sepiolite and kaolinite, the removal efficiency and removal rate of modified clays increased with the decrease of ionic strength (Fig. 1c and d). In $1 \% \mathrm{NaCl}$ solution, only $70 \%$ of cells were removed after $480 \mathrm{~min}$. When ionic strength reduced to $0 \% \mathrm{NaCl}$, over 95\% MA cells were removed after $75 \mathrm{~min}$. This result indicated that chitosan modification could make the clay technique more effective in freshwater systems.

\subsection{Effect of $p H$}

Fig. 2 showed that between $\mathrm{pH} 6.5$ and 9.0, removal efficiency $\left(Q_{8 \mathrm{~h}}\right)$ of chitosan-modified sepiolite was not affected significantly ( $>80 \%$ ). But $Q_{8}$ h dropped dramatically beyond $\mathrm{pH} 10.0$.

\subsection{Effect of organic matter content}

As shown in Fig. 3, organic matter reduced the removal efficiency from $95 \%$ to $85 \%$ when humic acid concentration rose from $0 \mathrm{mg} / \mathrm{L}$ to $40 \mathrm{mg} / \mathrm{L}$. In general, $Q_{8}$ h of chitosan-modified sepiolite was not significantly affected by the organic matter content 
(a) Sepiolite

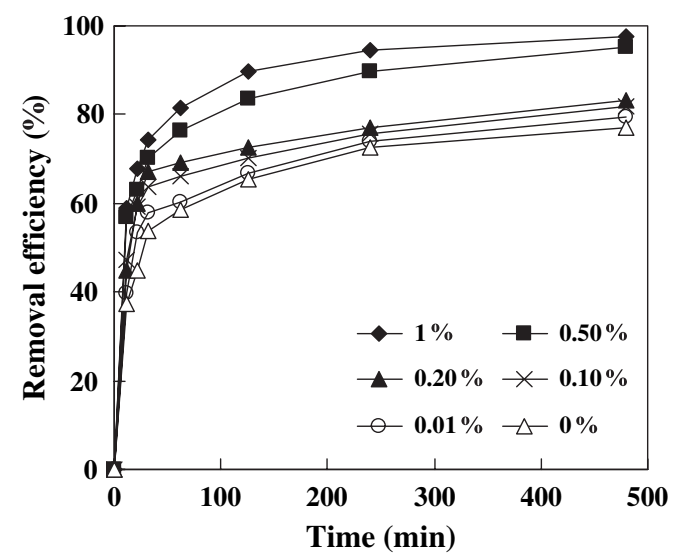

(b) Kaolinite

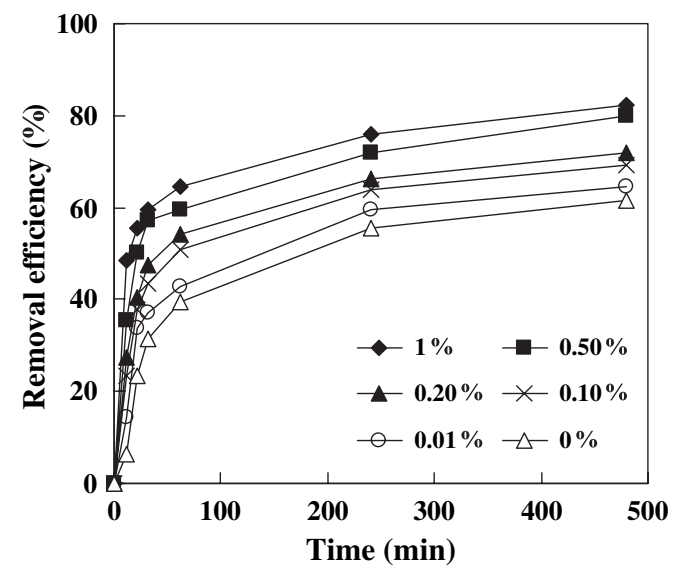

(c) Sepiolite + chitosan

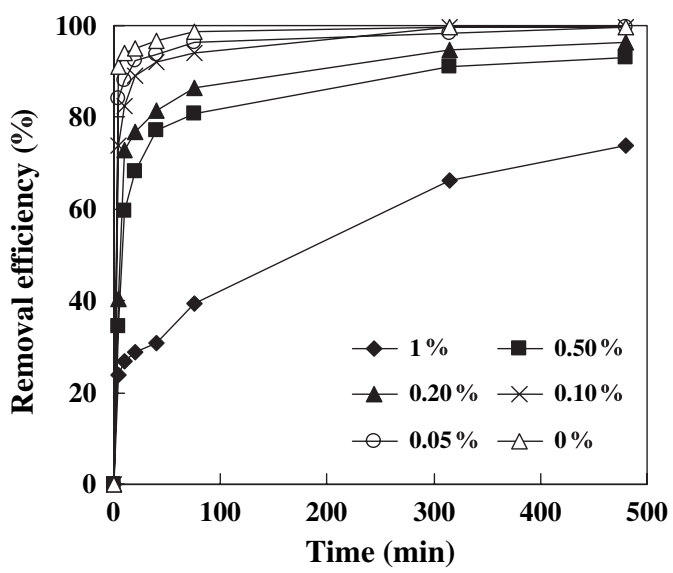

(d) kaolinite + chitosan

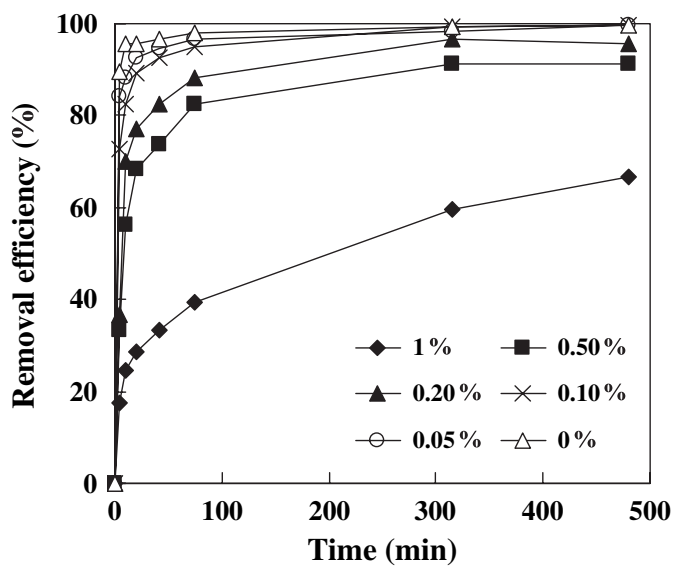

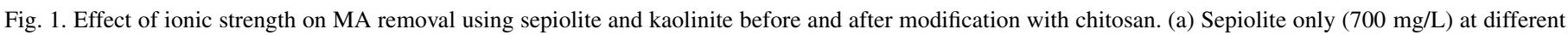

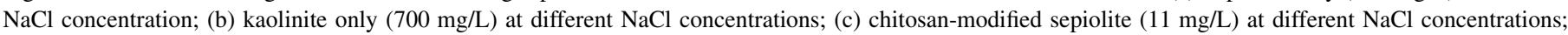
(d) chitosan-modified kaolinite $(11 \mathrm{mg} / \mathrm{L})$ at different $\mathrm{NaCl}$ concentrations.

\subsection{Effect of cell concentration}

The removal efficiency by chitosan-modified sepiolite increased remarkably with the increase of cell concentration (Fig. 4). At the chitosan-modified sepiolite loading of $11 \mathrm{mg} / \mathrm{L}, Q_{8 \mathrm{~h}}$ was about $15 \%, 86 \%$ and $95 \%$ at the initial

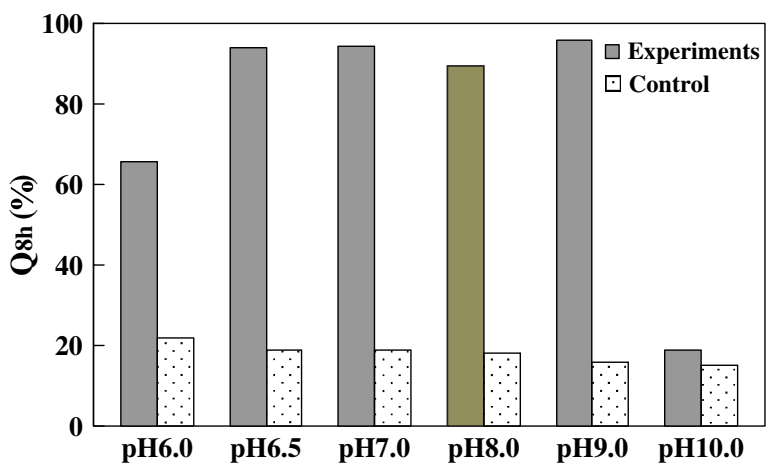

Fig. 2. Effect of $\mathrm{pH}$ on MA removal $\left(Q_{8 \mathrm{~h}}\right)$ using chitosan-modified sepiolite at a loading of $11 \mathrm{mg} / \mathrm{L}$. cell concentration of $2 \times 10^{9}$ cells $/ \mathrm{L}, 5 \times 10^{9}$ cells $/ \mathrm{L}$, and $9 \times 10^{9}$ cells/L, respectively. It is therefore important to estimate the best clay/soil loading according to the cell concentration conditions.

\subsection{Effect of growth phase}

Both removal efficiency and removal rate at the same initial cell concentration of $4.86 \times 10^{9}$ cells/ $\mathrm{L}$ and the sepiolite loading of $200 \mathrm{mg} / \mathrm{L}$ was in the order of late lag phase $>$ early senescence phase $>$ middle logarithmic phase $>$ late logarithmic phase (Fig. 5). Since cell concentration is usually low at lag phase in practical situations, the best timing for clearing up blooms using clays is around the early senescence phase.

\subsection{Field enclosure experiment}

Table 1 and Fig. 6 show the short term effect after applying $1.5 \mathrm{~kg}$ chitosan-modified local soils onto the $32 \mathrm{~m}^{2}$ enclosure (1.9 $\mathrm{m}$ deep) to remove the harmful cyanobacterial blooms 


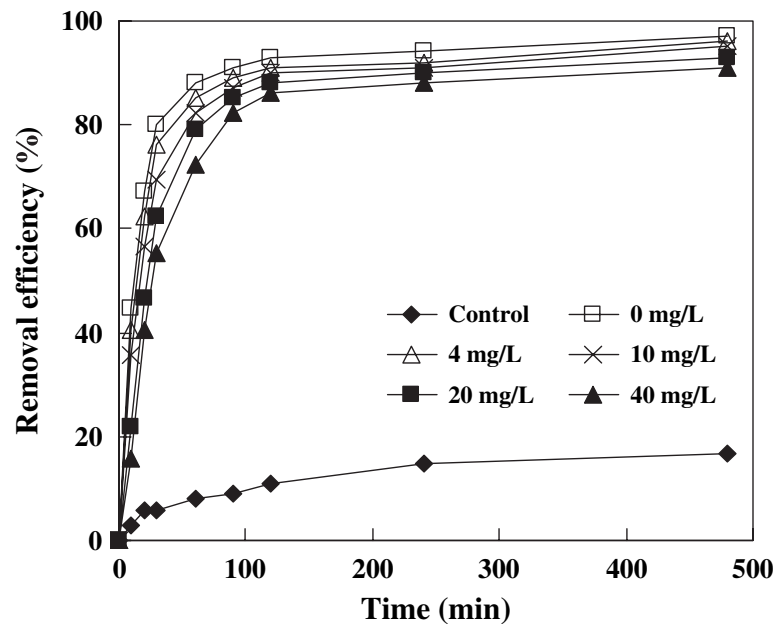

Fig. 3. Effect of humic acid on MA removal using chitosan-modified sepiolite at a loading of $11 \mathrm{mg} / \mathrm{L}$.

(equivalent to a clay loading of $50 \mathrm{~g} / \mathrm{m}^{2}$ or $0.025 \mathrm{~g} / \mathrm{L}$ ). About 99\% chlorophyll- $a$ and $42 \%$ dissolved phosphate were removed from the water column, while secchi depth increased from $15 \mathrm{~cm}$ to $85 \mathrm{~cm}$, within $5 \mathrm{~h}$ of the application of chitosan-modified local soils (Table 1). The concentration of chlorophyll- $a$ maintained the low level throughout the next 33 days (Fig. 7). However, dissolved phosphate was increased to a peak value (about double that before the treatment) by day 16, although it appeared to drop off after day 23 (Fig. 8). The mussels (Cristaria plicata (Leach)) and submerged macrophyte (Myriophyllum spicatum) in the operating enclosure appeared in healthy status throughout the 33 days.

\section{Discussion}

\subsection{Flocculation mechanism of chitosan-modified clays/soils in freshwaters}

Suspended particles in natural waters are often negatively charged, resulting in the formation of an electrical double

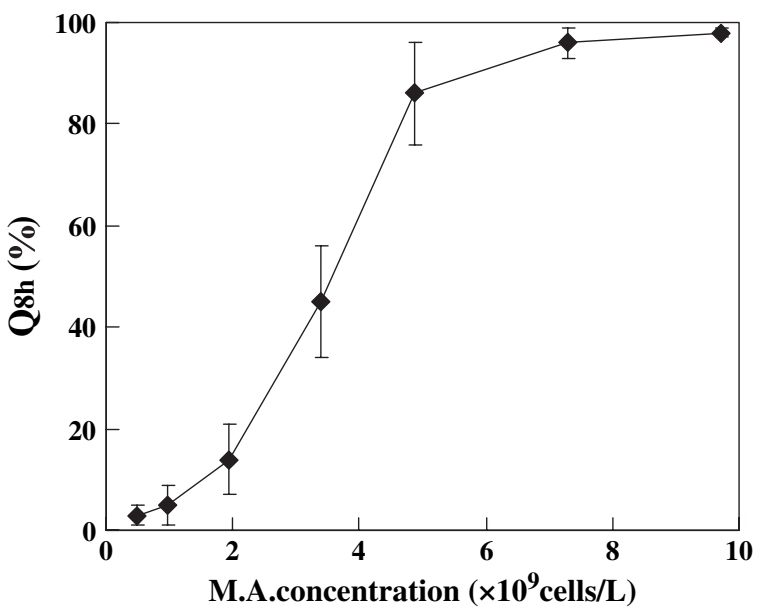

Fig. 4. Effect of cell concentration on MA removal $\left(Q_{8 \mathrm{~h}}\right)$ using chitosanmodified sepiolite at a loading of $11 \mathrm{mg} / \mathrm{L}$.

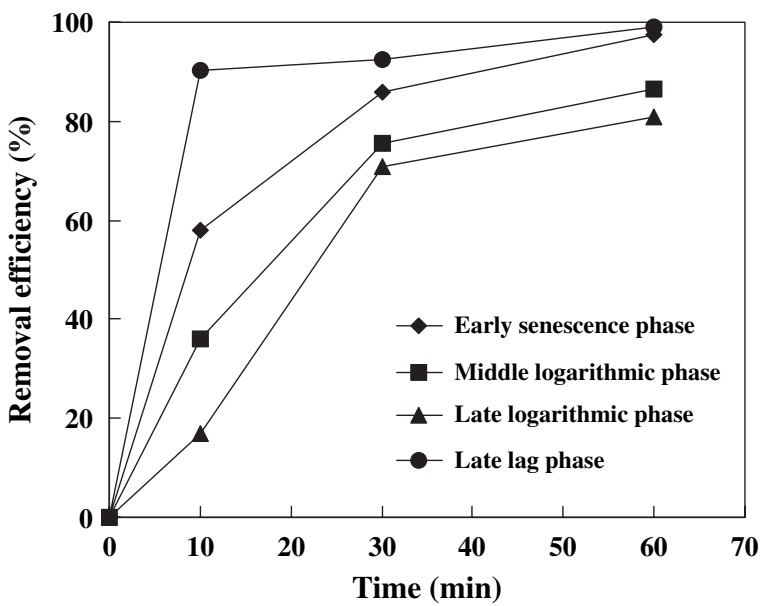

Fig. 5. Effect of growth phase on MA removal using unmodified sepiolites.

layer at the solid-water interfaces. Particles with thinner electrical double layers are easier to coagulate because of less repulsion. As salinity increases the thickness of the electrical double layer decreases because of the compression of the electrolytes and the effective collision probability of the granules increases, resulting in an increased degree of coagulation between the clay particles. It is estimated that the collision probability in freshwater is only one-tenth of that in seawater (Chang et al., 1993; Han and Kim, 2001). This explains the ionic strength effect on the flocculation of unmodified clays in Fig. 1a and b.

However, since ionic strength had a contrast effect on normal clays and chitosan-modified clays, the characteristics of chitosan must play an important role. Chitosan is not a polymer with a unique chemical composition, but rather a whole family of acid-soluble linear heteropolysaccharides composed of varying amounts of (1-4)-linked 2-acetamido2-deoxy-b-D-glucopyranose (GlcNAc) and 2-amino-2-deoxyb-D-glucopyranose $(\mathrm{GlcN})$. The protonation of amino groups of GlcN in solution makes chitosan positively charged and thereby very attractive for flocculation and different kinds of binding applications. Chitosan, a typical cationic flocculant (Strand et al., 2002), can also flocculate colloidal particles by netting and bridging just as other polymers. The algal removal efficiency of modified clays/soils with chitosan can thus be improved considerably by enhancing the netting and bridging function and by modifying the surface charge of the clay, with the former factor playing the dominant role (Zou et al., 2005, 2006). With the increase of ionic strength, a large amount of negative ions would gather around $-\mathrm{NH}_{3}^{+}$groups, leading to a decrease of the repulsion from positive charges of protonated amino groups (Jiang and Han, 1998; Wang and Xu, 1994). This prevents the unfolding of the molecular chain, thereby weakening its netting and bridging properties. Therefore, the chitosan-modified clays show better algal removal efficiency under low ionic strength conditions (Fig. 1c and d) which is critically important for the application of the clay/soil technique in freshwater systems. 
Table 1

Short term results of the field enclosure experiment (14 October 2004)

\begin{tabular}{|c|c|c|c|c|}
\hline & \multicolumn{2}{|l|}{ Test enclosure } & \multicolumn{2}{|l|}{ Control enclosure } \\
\hline & 14 Oct, 2004, 11:00 h, before & 14 Oct, $2004,16: 00 \mathrm{~h}$, after & 14 Oct, 2004, 11:00 h & 14 Oct, 2004, 16:00 h \\
\hline Depth (m) & 1.9 & 1.9 & 1.9 & 1.9 \\
\hline $\mathrm{pH}$ & 8.22 & 7.85 & 8.22 & 8.22 \\
\hline Secchi depth $(\mathrm{cm})$ & 15 & 86 & 15 & 13 \\
\hline Dissolved phosphate (mg/L) & 0.020 & 0.014 & 0.016 & 0.018 \\
\hline Dissolved TP (mg/L) & 0.052 & 0.034 & 0.046 & 0.040 \\
\hline Chlorophyll- $a$ (mg/L) & 2.05 & 0.016 & 1.96 & 1.95 \\
\hline SD increased $(\mathrm{cm})$ & 71 & & - & \\
\hline Chlorophyll- $a$ removed (\%) & 99 & & - & \\
\hline
\end{tabular}

\subsection{Prospect of using chitosan-modified local soils to control harmful cyanobacterial blooms in lakes}

The field enclosure experimental results (Table 1 and Fig. 6) suggested that chitosan-modified local soils could be highly effective and quick for emergency needs to clear up harmful cyanobacterial blooms in lakes, reservoirs and ponds. The most distinguished character of this technique was that a removal efficiency of $99 \%$ was achievable in the field at an extremely low soil loading of $0.025 \mathrm{~g} / \mathrm{L}$ or $50 \mathrm{~g} / \mathrm{m}^{2}$. The lowest clay loading reported in previous literature is $0.25-$ $2.5 \mathrm{~g} / \mathrm{L}$ from a jar-test experiment in the laboratory ( $\mathrm{Yu}$ et al., 1994a,b, 1995; Sengco et al., 2001), while a removal efficiency of $98 \%$ was obtained in a laboratory jar-test at a chitosan-modified clay/soil loading of $0.011 \mathrm{~g} / \mathrm{L}$ (Zou et al., 2006). The remaining problem for this technique is that, after
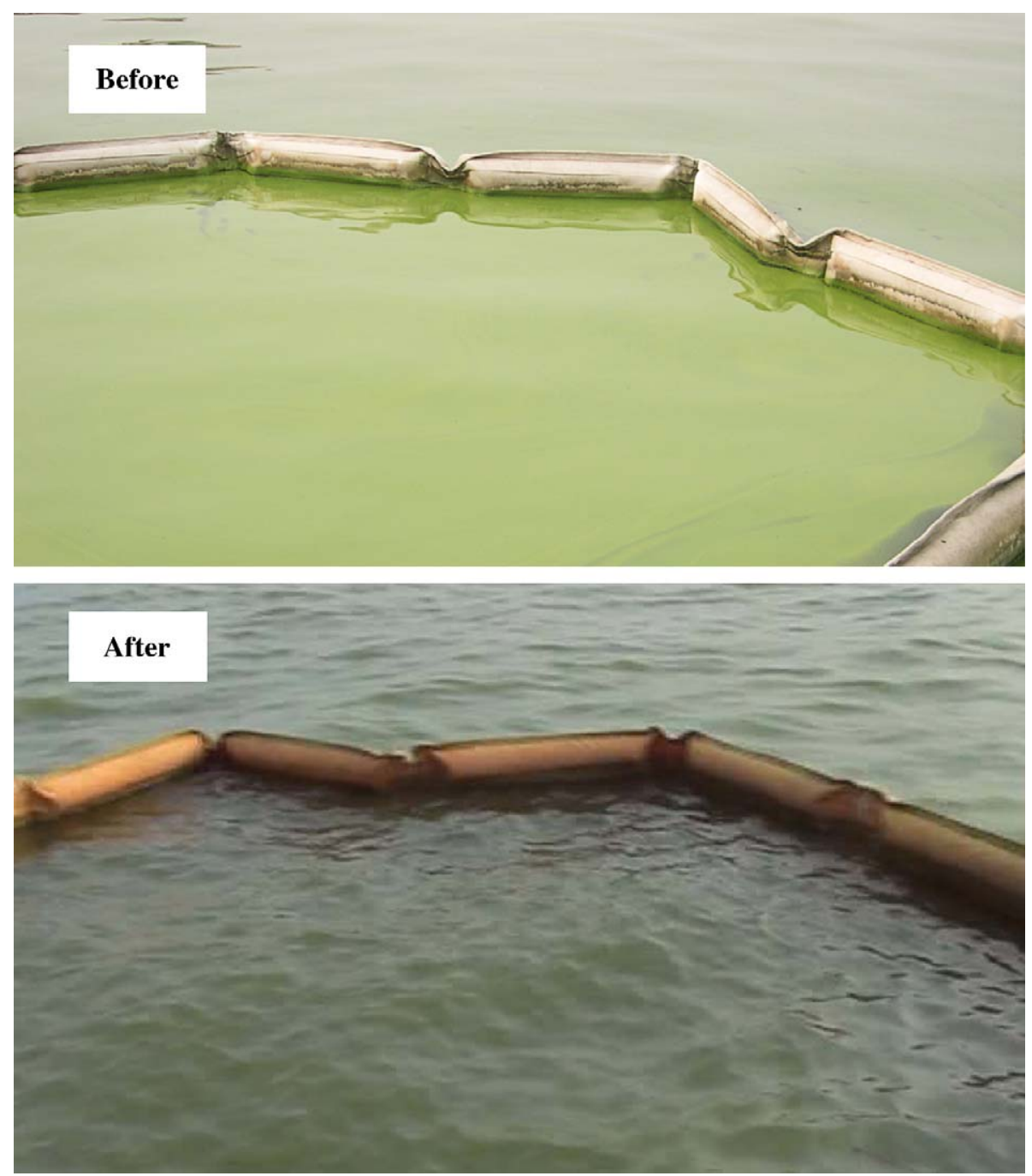

Fig. 6. Photographs showing the surface conditions of enclosures before and after the field treatment experiment. 


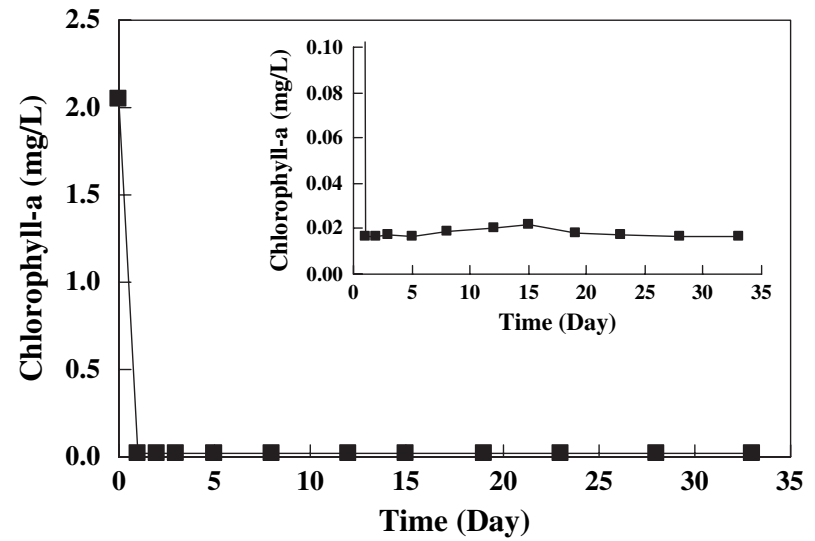

Fig. 7. Concentration changes of chlorophyll- $a$ in the field enclosure after the blooms were removed using chitosan-modified local soils.

cyanobacterial cells are biodegraded in the sediment, more phosphate that was previously stored in the cells could be released into the water (Fig. 8). This forms the next research direction in this area. In fact, we have already found a new modification method that may permanently fix phosphate into the sediment so that phosphate will not be released into the water even when the sediment is re-suspended (results not presented here). As a natural process, after harmful cyanobacterial blooms each year, part of the over-enriched phosphorus in the cells will finally be released into the water and accumulated in the sediment. Since the re-suspension of the sediment is often unavoidable in shallow lakes, it is lacking in a net phosphate burial mechanism in shallow lakes that is crucial for the development of eutrophication related to the second pollution from the sediment. To develop novel techniques that could not only clear up harmful algal blooms but also irreversibly fix the over-enriched phosphate into the sediment will be a very important research direction in the control of harmful cyanobacterial blooms/eutrophication in lakes.

\section{Conclusions}

(1) High ionic strength was beneficial to the removal of MA cells by unmodified clays due to the reduction of the

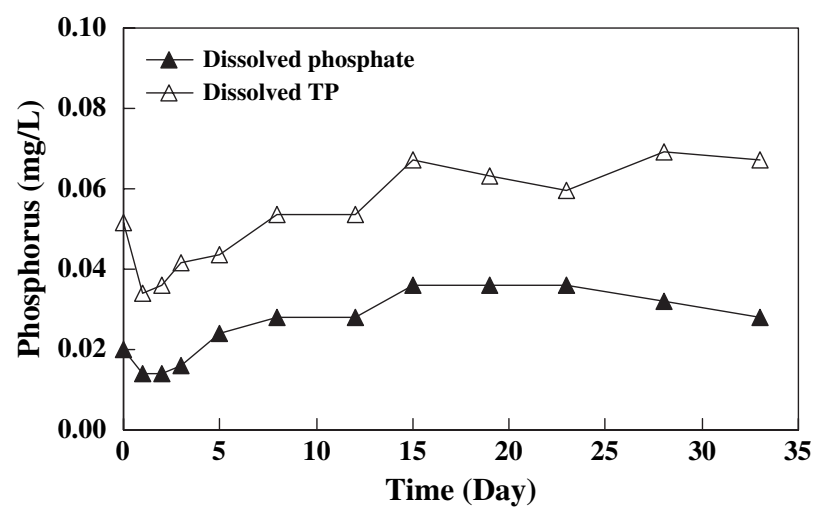

Fig. 8. Concentration changes of phosphorus in the field enclosure after the blooms were removed using chitosan-modified local soils. thickness of the electrical double layer which enhances the collision probability of the granules. On the contrary, chitosan-modified clays showed a higher removal efficiency of MA cells under low ionic strength conditions. This was because at higher ionic strength the repulsion of positively charged groups in chitosan molecule chains were shielded by a large number of ions that reduce the extensibility of the chitosan molecule, leading to the reduction of netting and bridging between particles.

(2) Good removal efficiency was obtained with chitosanmodified sepiolite at $\mathrm{pH} 6.0$ to 9.0 , followed by a significant drop at $\mathrm{pH} 10.0$.

(3) Organic matter content (up to $40 \mathrm{mg} / \mathrm{L}$ humic acid) had a small negative effect (an efficiency reduction of less than $10 \%$ ) on the cell removal efficiency.

(4) The removal efficiency increased dramatically with cell concentration. In practice, it is important to estimate the best clay/soil loading according to the cell concentration conditions.

(5) In practice, blooms could be removed more effectively by clays around the early senescence growth phase.

(6) Both laboratory and field enclosure experiments showed that chitosan-modified local soils are highly effective for treating blooms in Taihu Lake. The chitosan modification technique can not only turn local clays or soils into highly effective flocculants, but is also very powerful in reducing the clay loading, which is crucial for large scale field applications. It is very important to develop novel techniques that can not only flocculate algal cells but also permanently/ irreversibly fix the over-enriched phosphate into the sediment.

\section{Acknowledgements}

The research was funded by the National Key Technologies R\&D Programme (2002AA601011), Chinese NNSF Grant No. 20177029 and National Key Project for Basic Research on the Processes of Lake Eutrophication and the Mechanism of Cyanobacterial Blooming (2002CB412308).

\section{References}

Baek, S.H., Sun, X.X., Lee, Y.J., Wang, S.Y., Han, K.N., Choi, J.K., Noh, J.H., Kim, E.K., 2003. Mitigation of harmful algal blooms by sophorolipid. Journal of Microbiology and Biotechnology 13, 651-659.

Chang, Q., Fu, J.Y., Li, Z.L., 1993. Principles of Flocculation (Chinese). Lanzhou University Press, Lanzhou, pp. 109-110.

Chen, H., Pan, G., Zhang, M.M., 2004. Effect of growth phase on the flocculation of algal cells using clays. Environmental Science 6, 85-88 (in Chinese).

Han, M.Y., Kim, W., 2001. A theoretical consideration of algae removal with clays. Microchemical Journal 68, 157-161.

Jiang, W.H., Han, S.J., 1998. Sensibility of the chitosan to the addition of salt by viscometry. ACTA Polymerica Sinica 5, 567-572 (in Chinese).

Pan, G., Zhang, M.M., Chen, H., Zou, H., Yan, H., 2006. Removal of cyanobacterial blooms in Taihu Lake using local soils I. Equilibrium 
and kinetic screening on the flocculation of Microcystis aeruginosa using commercially available clays and minerals. Environmental Pollution 141, $195-200$.

Pierce, R.H., Henry, M.S., Higham, C.J., Blum, P., Sengco, M.R., Anderson, D.M., 2004. Removal of harmful algal cells (Karenia brevis) and toxins from seawater culture by clay flocculation. Harmful Algae 3, 141-148.

Sengco, M.R., Li, A., Tugend, K., Kulis, D., Anderson, D.M., 2001. Removal of red- and brown-tide cells using clay flocculation. I. Laboratory culture experiments with Gymnodinium breve and Aureococcus anophagefferens. Marine Ecology Progress Series 210, 41-53.

Strand, S.P., Nordengen, T., Hstgaard, K., 2002. Efficiency of chitosans applied for flocculation of different bacteria. Water Research 36, $4745-4752$.

Sun, X.X., Lee, Y.J., Choi, J.K., Kim, E.K., 2004. Synergistic effect of sophorolipid and loess combination in harmful algal blooms mitigation. Marine Pollution Bulletin 48, 863-872.

Wang, W., Xu, D.S., 1994. Rheological properties for concentrated solution of chitosan. Dependence of solvents. Acta Chimica Sinica 52, 243-247 (in Chinese).
Yu, Z.M., Zou, J.Z., Ma, X.N., 1994a. Application of clay to removal of red tide organism I. Coagulation of red tide organism with clays. Chinese Journal of Oceanology and Limnology 12, 193-200.

Yu, Z.M., Zou, J.Z., Ma, X.N., 1994b. Application of clay to removal of red tide organism II. Coagulation of different species of red tide organism with montmorillonite and effect of clay pretreatment. Chinese Journal of Oceanology \& Limnology 12, 316-324.

Yu, Z.M., Zou, J.Z., Ma, X.N., 1995. Application of clay to removal of red tide organism III. The coagulation of kaolin on red tide organism. Chinese Journal of Oceanology \& Limnology 13, 62-70.

Zou, H., Pan, G., Chen, H., 2004. Flocculation and removal of water bloom cells Microcystis aeruginosa by chitosan-modified clays. Environmental Science 25, 40-43 (in Chinese).

Zou, H., Pan, G., Chen, H., 2005. Effects of ionic strength on the flocculation and removal of cyanobacterial cells of Microcystis aeruginosa by clays. Environmental Science 26, 148-151 (in Chinese).

Zou, H., Pan, G., Chen, H., Yuan, X.Z., 2006. Removal of cyanobacterial blooms in Taihu Lake using local soils II. Effective removal of Microcystis aeruginosa using local soils and sediments modified by chitosan. Environmental Pollution 141, 201-205. 